DOI: $10.21802 /$ artm.2019.4.12.50.

УДК 615.8+616-089+616.366

\title{
АНАЛІЗ МЕТОДИКИ РЕАБІЛІТАЦЇ ПАЦІЕНТІВ ПІСЛЯ ХОЛЕЦИСТЕКТОМІЇ НА ВІДДАЛЕНОМУ ЕТАПІ РЕАБІЛІТАЦІЇ У ВІДДІЛЕННІ «ЛАВАНДА» САНАТОРНО-КУРОРТНОГО КОМПЛЕКСУ «МОРШИНКУРОРТ»
}

\author{
Н.Р. Голод ${ }^{1}$, І.К. Чурпій${ }^{1}$, Н.Г. Слободян ${ }^{2}$, Н.М. Мукан ${ }^{2}$, О.В. Янів ${ }^{1}$ \\ ${ }^{1}$ Івано-Франківський начіональний медичний університет, кафедра фізичної реабілітаиії, ерготерапії \\ та фізичного виховання, м. Івано-Франківськ, Украӥна, \\ ORCID ID:0000-0003-0996-6920,e-mail:natasha_777@i.ua,afex@ukr.net, \\ ORCID ID: 0000-0003-1735-9418,e-mail:ch.igor.if@gmail.com, \\ ORCID ID:0000-0003-0921-3304, e-mail: olesiayaniv333@gmail.com; \\ ${ }^{2}$ ДП СКК «Моршинкурорт» ЗАТ «Укрпрофоздоровниия», м. Моршин, Львівська обл., Україна.
}

Резюме. Мета дослідження: провести аналіз методики реабілітації пацієнтів після холецистектомії на віддаленому етапі реабілітації у Відділенні «Санаторій «Лаванда»» санаторно-курортного комплексу «Моршинкурорт».

Методи дослідження: аналіз методів реабілітації пацієнтів у Відділенні «Санаторій «Лаванда»» санаторно-курортного комплексу «Моршинкурорт» за 2017 та 2018 роки, синтезу та аналізу.

У Відділенні «Санаторій «Лаванда»» проходять реабілітацію пацієнти у підгострому періоді після оперативних втручань на органах травлення (відділення на 60 ліжок). У 2018 році виписано 359 реабілітаційних хворих. Ваннами охоплено 331 хворого, тобто 92,7 \%, по 8,6 процедур на хворого. Відпущено 2833 ванни. Лікувальні душі приймало 179 осіб, проведено 1510 процедур, по 8,4 процедур на хворого, охоплено 50,1 \% хворих. 3,6 \% хворих приймало місцевий висхідний душ та 5,6 \% приймали душ Шарко, 97 \% охоплено фізіотерапією. Найчастіше призначалась фітотерапія (47\%), магнітотерапія (59,9\%), лазеротерапія (10,6 \%), СКТ $(44,5 \%)$, інгаляція $(15,1 \%)$, світлолікування $(9,5 \%)$, ультразвукова терапія $(19,9 \%)$, озекерітолікування $(24,6 \%)$, мікроклізми (67,5\%), кишкові зрошення $(8,4 \%)$, оксигенотерапія $(25,5 \%)$.

Висновки. Кадрові, природні, матеріальні ресурси та лікувальна діяльність відділення свідчать про великий реабілітаційний потенціал даного закладу при різних соматичних захворюваннях. Проте у світлі реформ та нововведень, можливо, доцільно залучати у мультипрофесійну команду, яка здійснює реабілітаційний процес, також лікарів фізичної реабілітаційної медицини, а замість інструктора ЛФК ввести посаду фізичного терапевта, для застосування більш нових методів фізичної терапії з точки зору доказової медицини.

Ключові слова: реабілітація, холецистектомія, санаторно-курортний етап.

Вступ. Відділення «Санаторій «Лаванда»»» ЗАТ «Укрпрофоздоровниця» містить 388 ліжок гастроентерологічного профілю. У відділенні проходять реабілітацію особи із різних підприємств України: ППО ТОВ «Побужський феронікелевий комбінат», ВАТ «Запорізький залізорудний к-т», ВАТ «Металургійний к-т «Азовсталь»», ППО ВАТ «Полтавський ГЗК»» та інших установ, також у санаторії отримують реабілітаційні послуги фізичні особи та потерпілі внаслідок аварії на ЧАЕС, а також особи, направлені Міністерством праці та соцполітики та Фондом соціального страхування з нещасних випадків.

Результати досліджень та їх обговорення. У санаторії функціонує реабілітаційне відділення для хворих із захворюваннями печінки та жовчовивідних шляхів на 60 ліжок. У 2018 році отримали послуги 359 реабілітаційних пацієнтів (12 хворих було перехідних з 2017 року).

У Відділенні «Санаторій «Лаванда»»» працює 13 лікарів, 16 медичних сестер, 1 інструктор ЛФК на 0,5 ставки.
Структура медичного персоналу відділення подана на рис. 1 .

Для обстеження хворих у ДП «СКК «Моршинкурорт»») функціонують клінічна, біохімічна, цитологічна, імунологічна лабораторії, у яких використовується 110 методик, які уніфіковані.

3 метою більш глибокого обстеження гастроентерологічних та інших хворих працюють кабінети ендоскопії та рентгенодіагностики, ультразвукової діагностики, багато хворих направляється в кінці лікування на обстеження для визначення ефективності проведеної реабілітації. За 2018 р. всі хворі виписані із покращенням, без покращення хворих не було.

У своїй практиці лікуючі лікарі діагностують і супутні захворювання. Цим хворим проводиться лікування супутніх захворювань після консультації вузьких спеціалістів. Хворий має можливість, крім основного гастроентерологічного захворювання, пролікувати і супутні хвороби. 


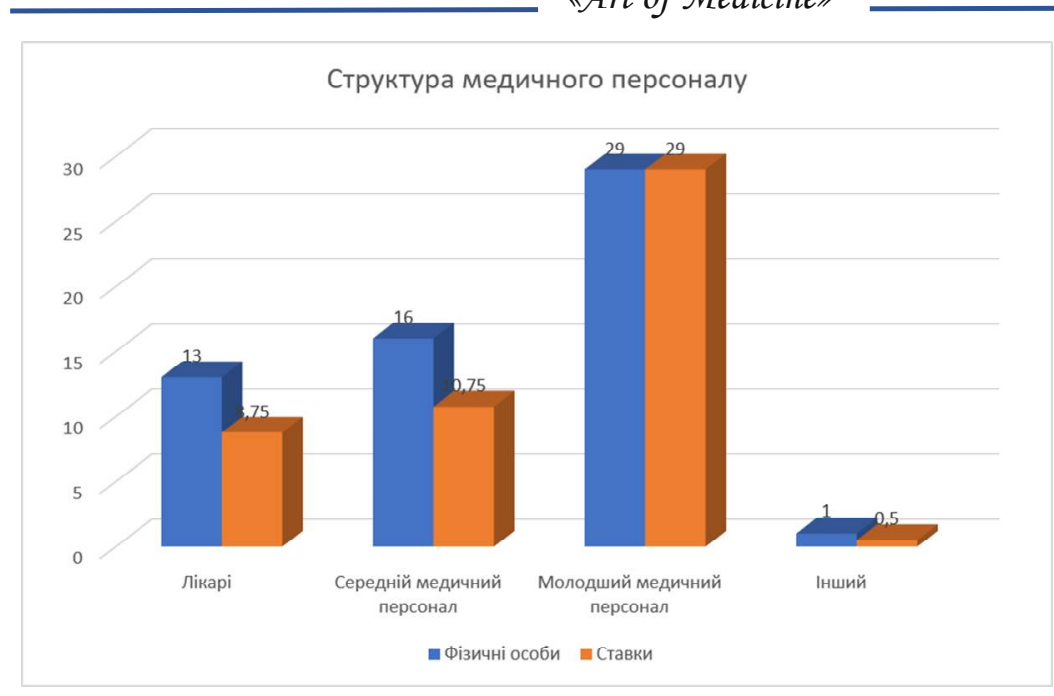

Рис. 1. Структура медичного персоналу Відділення «Санаторій «Лаванда»» санаторнокурортного комплексу «Моршинкурорт»

Щоквартально на виробничих нарадах аналізується якість медичної допомоги хворим шляхом експертної оцінки історій хвороби, що проводиться по різних напрямках: своєчасність і повноцінність обстежень, якості і кваліфікованості призначеного лікування, якості професійної праці персоналу, якості ведення медичної документації. Лікарямиспеціалістами разом 3 лікуючими лікарями обговорюються питання якості лікування i діагностики, можливі помилки при призначенні лікування та шляхи їх виправлення та недопущення. За результатами виробничих нарад приймаються рішення, що направлені на покращення медичного обслуговування хворих.

Впроваджені комп'ютерні системи ведення обліково-звітної медичної документації і планування лікувального процесу та комп'ютерний аналіз його діяльності. У Відділенні „Бальнеологічна лікарня” курорту «Моршин» ведеться щоденний комп'ютерний облік відпущених процедур, аналізується вартість лікування на один ліжко/день по кожній оздоровниці.

Комп’ютерний аналіз медичної діяльності ведеться на основі «Статистичної карти хворого, що вибув із стаціонару (Ф № 066/0)», що дає можливість зробити етапну оцінку якості діагностики, лікування та реабілітації, відповідно до прийнятих стандартів кожного лікаря, відділення, оздоровниці. У комп'ютерній мережі ДП «СКК «Моршинкурорт»» експлуатується нормативно-довідкова система „Нормативні акти України", яка щотижня оновлюється загальнодержавними документами. Також функціонує комп'ютерний аналіз наявності місць у приймальних відділеннях оздоровниць.

При виписці хворих з санаторію оцінюється ефективність проведеного лікування, відображається у епікризі та виписці, а також додаються рекомендації, чим здійснюється зв'язок із закладом, що направив хворого на лікування.

У санаторії проводяться регулярно лікарські заняття, на яких заслуховуються інформаційні огляди публікацій. Після проведення основних клінікодіагностичних обстежень лікуючий лікар, якщо потрібно із завідувачем відділення, або начмедом, розробляє план подальших лікувально-оздоровчих заходів.
За показниками призначаються консультації спеціалістів ЛКК. Контроль за виконанням призначень лікаря здійснює старша медсестра відділення разом із патронажною медсестрою під керівництвом лікуючого лікаря.

На гастроентерологічному курорті велике значення має дієтичне харчування і відповідність приготування дієтичних страв № 1, 1a, 2, 4, 5П, 9, 15, ПР. Результати органолептичних і смакових якостей записуються в меню-розкладці черговим лікарем. Для забезпечення правового статусу по захисту пацієнтів створено куток споживача, де пацієнти можуть ознайомитись із своїми правами та обов'язками, вартістю путівки, лікувально-діагностичного комплексу, інформацією про платні послуги.

У санаторії кожний місяць згідно 3 планом проводяться лікарські і сестринські конференції, заняття $з$ молодшими медичними сестрами, постійно проводяться семінарські заняття з клініки, діагностики, лікування і профілактики карантинних інфекцій, гострих інфекційних захворювань, надання невідкладної медичної допомоги.

На базі відділення науковцями ІваноФранківського національного медичного університету кафедри фізичної реабілітації, ерготерапії проводиться наукове дослідження на тему: «Теоретикометодичні основи фізичної терапії хворих після лапароскопічної холецистектомії», досліджується ефективність проведеного реабілітаційного втручання.

У Відділенні існує лекторій для відпочивальників санаторію, регулярно проводяться лекції та бесіди з людьми, що відпочивають.

Наявність в санаторії та курорті «Моршин» спеціалізованих лікувально-діагностичних кабінетів дає можливість максимально повно обстежити хворих. На курорті працюють: клінічна, біохімічна, бактеріологічна та імунологічна лабораторії; існують кабінет рентгенологічного дослідження, а також УЗД та ФЕГДС, РН-метрія, ЕКГ обстеження.

Лікарями широко використовуються природні фактори в лікувальному комплексі: пиття мінеральної води; мінеральні ванни; мінерально-хвойні ванни; перлинні ванни; мінерально-бішофітові; мінерально-пєлоїдо-бішофітові; мінерально-загальновихрові; вуглекислі ванни; мінерально-сірчані; міне- 
рально-родонові; сухі вуглекислі ванни; карбоксітерапія; місцеві вихрові ванни (ручні та ніжні); аплікації озокериту; електрофорез торф'яної грязі; кишкові зрошення мінеральною водою; гінекологічне зрошення; гідромасаж ясен; аромофітотерапія; оксігенно терапія; синглентно-киснева терапія 4 сумішів; фітотерапія та озоно-фітотерапія; спелеотерапія.

Досягнення високого рівня якості санаторно-курортної допомоги передбачає систематичне i цілеспрямоване вдосконалення ресурсів: кадри, матеріально-технічне та фінансове забезпечення; організаційно-правових засад, асортименту послуг, що пропонуються.

Для прийняття управлінських рішень збір інформації проводиться 3 допомогою статистичної карти вибулого санаторного хворого, яка обробляється статистично, у результаті чого отримується модель кінцевого результату (форма 68 звіту) з показниками ефективності лікування. Лікування проводиться згідно $з$ стандартами лікувально-діагностичного процесу хворих із захворюваннями органів травлення.

У своїй діяльності використовують наявні місцеві курортні фактори: джерела №1, 6, 4 для внутрішнього прийому, мінеральні ванни, душі, аплікації озокериту, електрофорез грязі, кишкові зрошення, фізіотерапевтичні процедури, психотерапію, рефлексотерапію, масаж, синглетну оксигенотерапію.

Фізіотерапевтичний кабінет працював у Відділенні «Санаторій «Лаванда»» до листопада 2010 р. У листопаді 2010 р. був переведений в Відділення «Водолікарня». Лікуванням фізіотерапією охоплено біля 91 \% пацієнтів. У 2018 році хворим назначали такі процедури: магнітотерапію - 2403 хворим, проведено 17873 процедури; лазеротерапію - 968 хворим, проведено 7103 процедури; електролікування - 593 хворим, проведено 3943 процедури; ультразвукова терапія - 943 хворим, проведено 6533 процедури; КВЧ-терапію - 299 хворим, проведено 2297 процедур; світлолікування - 523 хворим, проведено 2788 процедур, а також СКТ-терапію призначено 938 хворим, проведено 8539 процедур, ОГТтерапію було призначено 470 хворим, проведено 4346 процедур, інгаляцій - 1080 хворим, проведено 8666 процедур; дарсанвалізація - 446 хворим, проведено 3195 процедур.

У кабінеті мікроклізм за 2018 рік прийнято 3093 особами, відпущено процедур - 27270; в середньому на 1 особу припадає 8,8 мікроклізми, охоплено 82,4 \%, курсовість мікроклізм висока.

Бальнеологічне-, грязе- та озокеритолікування хворі санаторію «Лаванда» приймають в загальнокурортній «Бальнеологічній лікарні» курорту «Моршин».

Мінеральні ванни в 2018 р. призначено 4110 хворим, було отримано 29653 процедури, по 6,9 процедур на одного хворого.

Душі (циркулярний, висхідний та Шарко) у 2018 р. прийняло 1528 хворих, тобто 40,7 \%, по 6,7 процедури на хворого, відпущено 10176 процедур, а в 2017 p. - 1791 хворих, тобто 41,6 \%, по 7,3 процедури на хворого, відпущено 13150 процедур. Відсоток охоплення цими процедурами дещо зменшився.
Озокеритолікування у 2018 р. приймало 1304 хворих, відпущено 8416 процедур, охоплено 34,7 \% хворих, по 6,5 процедур на хворого.

Електрогрязелікування у 2018p. прийняло 274 хворих, проведено 2042 процедури, по 7,5 процедур на хворого, що становить 7,3\%.

Кишкові зрошення в 2018p. прийняло 1060 хворих, що становить 28,2 \% хворих, по 2,3 процедури на хворого, всього відпущено 2444 процедури. Кількість відпущених процедур дещо зменшилась.

Також хворі санаторію «Лаванда» приймали наступні процедури: гінекологічні зрошення, мінерально-, йодобромні спринцювання, грязьові, тампони вагінальні та ректальні, інгаляції, аерозольтерапію, масаж урологічний, гінекологічний, загальний масаж, аромофітотерапію, спелєотерапію.

Хворі Відділення «Санаторій «Лаванда»» проконсультовані: 1022 хв. -гінекологом, 849 хв. урологом, зроблено масаж простати, інстиляції сечового міхура - 47 хв., проведено 177 процедур; 784 хв. - невропатологом, 570 хв. - отоларингологом, 796 хв. - хірургом, 295 хв. - дерматовенерологом, 585 хв. офтальмологом, 460 хв. - дієтологом, 179 хв. - фізіотерапевтом, 51 хв. - проктологом, a RRS проведено 1464 хв. Всього у 2018 р. проведено 5515 консультацій вузькими спеціалістами, на одного хворого приходилось - 1,5. Проведено 24257 прийомів лікарями, тобто по 6,5 прийомів на хворого. Це дуже висока цифра, враховуючи, що тільки 37,5 \% лікувалось повний термін 21-24 дні.

За 2018 р. було зроблено знімків - 265 хворим, зроблено 838 обстежень і рентгенпросвічень 229 хв., зроблено 756 обстежень. Відсоток охоплення дещо збільшився.

За 2018 р. в клінічній лабораторії обстежено 3920 хв., проведено 47165 обстежень, по 12 на хворого.

У кабінеті ендоскопії відділення «Санаторій «Лаванда»» за 2018 р. обстежено 1251 хворого. Охоплено 33,3 \% хворих, проведено 1464 хворим ректоманоскопію, тобто охоплено $39 \%$, а за 2017 р. обстежено 1123 хворих. Охоплено - 26 \% хворих. Проведено 1574 хв. ректоманоскопії, тобто охоплено $36,6 \%$.

За 2018 р. обстежено методом ультразвукової діагностики 3899 хворих, проведено 9496 обстежень, по 2,4 обстежень на хворого. Охоплено хворих 103,9\%. Функціонує кабінет рефлексотерапії. Використовуються наступні лікувальні методики: класична голкотерапія, аурікулотерапія, голки-банки НАCI, аплікатор Ляпко, припалювання полинними цигарками, мануальна терапія. Функціонує стоматологічний кабінет.

У «Санаторій «Лаванда»» $є$ один зал площею 112 кв. м. для проведення лікувальної фізкультури. Штат: 1 інструктор 3 фізкультури (з вищою освітою).

Кабінет ЛФК працює кожен день. Шість разів на тиждень.

Проводяться групові заняття й індивідуальні. Упродовж робочого часу відпускається механотерапія.

За 2018 рік у залі ЛФК оздоровилось лікувальною фізкультурою 938 чол., надано всього 8542 
процедури. Крім того, 61 людина направлена на групову нордичну ходьбу. Проведено 534 заняття. Функціонує автоматичний масажний апарат «Релакс». Детальний аналіз діяльності кабінету ЛФК поданий у табл. 1.

Для обстеження хворих у ДП «СКК «Моршинкурорт»») функціонують клінічна, біохімічна, цитологічна, імунологічна лабораторії, у яких використовується 110 методик, які уніфіковані.

3 метою більш глибокого обстеження гастроентерологічних та інших хворих працюють кабінети ендоскопії та рентгенодіагностики, ультразвукової діагностики, багато хворих направляється в кінці лікування на обстеження для визначення ефективності проведеної реабілітації. За 2018 р. всі хворі виписані із покращенням, без покращення хворих не було.

У своїй практиці лікуючі лікарі діагностують i супутні захворювання. Цим хворим проводиться лікування супутніх захворювань після консультації вузьких спеціалістів. Хворий має можливість, крім основного гастроентерологічного захворювання, пролікувати і супутні хвороби.

Щоквартально на виробничих нарадах аналізується якість медичної допомоги хворим шляхом експертної оцінки історій хвороби, що проводиться по різних напрямках: своєчасність і повноцінність обстежень, якості і кваліфікованості призначеного лікування, якості професійної праці персоналу, якості ведення медичної документації. Лікарямиспеціалістами разом з лікуючими лікарями обговорюються питання якості лікування i діагностики, можливі помилки при призначенні лікування та шляхи їх виправлення та недопущення. За результатами виробничих нарад приймаються рішення, що направлені на покращення медичного обслуговування хворих.

Впроваджені комп'ютерні системи ведення обліково-звітної медичної документації і планування лікувального процесу та комп'ютерний аналіз його діяльності. У Відділенні „Бальнеологічна лікарня” курорту «Моршин» ведеться щоденний комп'ютерний облік відпущених процедур, аналізується вартість лікування на один ліжко/день по кожній оздоровниці.

Комп'ютерний аналіз медичної діяльності ведеться на основі «Статистичної карти хворого, що вибув із стаціонару (Ф № 066/0)», що дає можливість зробити етапну оцінку якості діагностики, лікування та реабілітації, відповідно до прийнятих стандартів кожного лікаря, відділення, оздоровниці. У комп'ютерній мережі ДП «СКК «Моршинкурорт»» експлуатується нормативно-довідкова система „Нормативні акти України”, яка щотижня оновлюється загальнодержавними документами. Також функціонує комп'ютерний аналіз наявності місць у приймальних відділеннях оздоровниць.

При виписці хворих з санаторію оцінюється ефективність проведеного лікування, відображається у епікризі та виписці, а також додаються рекомендаціiі, чим здійснюється зв'язок із закладом, що направив хворого на лікування.
У санаторії проводяться регулярно лікарські заняття, на яких заслуховуються інформаційні огляди публікацій. Після проведення основних клінікодіагностичних обстежень лікуючий лікар, якщо потрібно із завідувачем відділення, або начмедом, розробляє план подальших лікувально-оздоровчих заходів. За показниками призначаються консультації спеціалістів ЛКК. Контроль за виконанням призначень лікаря здійснює старша медсестра відділення разом із патронажною медсестрою під керівництвом лікуючого лікаря.

На гастроентерологічному курорті велике значення має дієтичне харчування і відповідність приготування дієтичних страв № 1, 1a, 2, 4, 5П, 9, 15, ПР. Результати органолептичних і смакових якостей записуються в меню-розкладці черговим лікарем. Для забезпечення правового статусу по захисту пацієнтів створено куток споживача, де пацієнти можуть ознайомитись із своїми правами та обов'язками, вартістю путівки, лікувально-діагностичного комплексу, інформацією про платні послуги.

У санаторії кожний місяць згідно з планом проводяться лікарські і сестринські конференції, заняття $з$ молодшими медичними сестрами, постійно проводяться семінарські заняття 3 клініки, діагностики, лікування і профілактики карантинних інфекцій, гострих інфекційних захворювань, надання невідкладної медичної допомоги.

На базі відділення науковцями ІваноФранківського національного медичного університету кафедри фізичної реабілітації, ерготерапії проводиться наукове дослідження на тему: «Теоретикометодичні основи фізичної терапії хворих після лапароскопічної холецистектомії», досліджується ефективність проведеного реабілітаційного втручання.

У Відділенні існує лекторій для відпочивальників санаторію, регулярно проводяться лекції та бесіди з людьми, що відпочивають.

Наявність в санаторії та курорті «Моршин» спеціалізованих лікувально-діагностичних кабінетів дає можливість максимально повно обстежити хворих. На курорті працюють: клінічна, біохімічна, бактеріологічна та імунологічна лабораторії; існують кабінет рентгенологічного дослідження, а також УЗД та ФЕГДС, РН-метрія, ЕКГ обстеження.

Лікарями широко використовуються природні фактори в лікувальному комплексі: пиття мінеральної води; мінеральні ванни; мінерально-хвойні ванни; перлинні ванни; мінерально-бішофітові; мінерально-пєлоїдо-бішофітові; мінерально-загальновихрові; вуглекислі ванни; мінерально-сірчані; мінерально-родонові; сухі вуглекислі ванни; карбоксітерапія; місцеві вихрові ванни (ручні та ніжні); аплікації озокериту; електрофорез торф'яної грязі; кишкові зрошення мінеральною водою; гінекологічне зрошення; гідромасаж ясен; аромофітотерапія; оксігенно терапія; синглентно-киснева терапія 4 сумішів; фітотерапія та озоно-фітотерапія; спелеотерапія.

Досягнення високого рівня якості санаторно-курортної допомоги передбачає систематичне i цілеспрямоване вдосконалення ресурсів: кадри, матеріально-технічне та фінансове забезпечення; органі- 
заційно-правових засад, асортименту послуг, що пропонуються.

Для прийняття управлінських рішень збір інформації проводиться 3 допомогою статистичної карти вибулого санаторного хворого, яка обробляється статистично, у результаті чого отримується модель кінцевого результату (форма 68 звіту) з показниками ефективності лікування. Лікування проводиться згідно $з$ стандартами лікувально-діагностичного процесу хворих із захворюваннями органів травлення.

У своїй діяльності використовують наявні місцеві курортні фактори: джерела №1, 6, 4 для внутрішнього прийому, мінеральні ванни, душі, аплікації озокериту, електрофорез грязі, кишкові зрошення, фізіотерапевтичні процедури, психотерапію, рефлексотерапію, масаж, синглетну оксигенотерапію.

Фізіотерапевтичний кабінет працював у Відділенні «Санаторій «Лаванда»» до листопада 2010 р. У листопаді 2010 р. був переведений в Відділення «Водолікарня». Лікуванням фізіотерапією охоплено біля $91 \%$ пацієнтів. У 2018 році хворим назначали такі процедури: магнітотерапію - 2403 хворим, проведено 17873 процедури; лазеротерапію - 968 хворим, проведено 7103 процедури; електролікування - 593 хворим, проведено 3943 процедури; ультразвукова терапія - 943 хворим, проведено 6533 процедури; КВЧ-терапію - 299 хворим, проведено 2297 процедур; світлолікування - 523 хворим, проведено 2788 процедур, а також СКТ-терапію призначено 938 хворим, проведено 8539 процедур, ОГТтерапію було призначено 470 хворим, проведено 4346 процедур, інгаляцій - 1080 хворим, проведено 8666 процедур; дарсанвалізація - 446 хворим, проведено 3195 процедур.

У кабінеті мікроклізм за 2018 рік прийнято 3093 особами, відпущено процедур - 27270; в середньому на 1 особу припадає 8,8 мікроклізми, охоплено 82,4 \%, курсовість мікроклізм висока.

Бальнеологічне-, грязе- та озокеритолікування хворі санаторію «Лаванда» приймають в загальнокурортній «Бальнеологічній лікарні» курорту «Моршин».

Мінеральні ванни в 2018 р. призначено 4110 хворим, було отримано 29653 процедури, по 6,9 процедур на одного хворого.

Душі (циркулярний, висхідний та Шарко) у 2018 р. прийняло 1528 хворих, тобто 40,7 \%, по 6,7 процедури на хворого, відпущено 10176 процедур, а в 2017p. - 1791 хворих, тобто 41,6 \%, по 7,3 процедури на хворого, відпущено 13150 процедур. Відсоток охоплення цими процедурами дещо зменшився.

Озокеритолікування у 2018 р. приймало 1304 хворих, відпущено 8416 процедур, охоплено 34,7 \% хворих, по 6,5 процедур на хворого.

Електрогрязелікування у 2018p. прийняло 274 хворих, проведено 2042 процедури, по 7,5 процедур на хворого, що становить 7,3\%.

Кишкові зрошення в 2018p. прийняло 1060 хворих, що становить 28,2 \% хворих, по 2,3 процеду- ри на хворого, всього відпущено 2444 процедури. Кількість відпущених процедур дещо зменшилась.

Також хворі санаторію «Лаванда» приймали наступні процедури: гінекологічні зрошення, мінерально-, йодобромні спринцювання, грязьові, тампони вагінальні та ректальні, інгаляції, аерозольтерапію, масаж урологічний, гінекологічний, загальний масаж, аромофітотерапію, спелсотерапію.

Хворі Відділення «Санаторій «Лаванда»» проконсультовані: 1022 хв. -гінекологом, 849 хв. урологом, зроблено масаж простати, інстиляції сечового міхура - 47 хв., проведено 177 процедур; 784 хв. - невропатологом, 570 хв. - отоларингологом, 796 хв. - хірургом, 295 хв. - дерматовенерологом, 585 хв. офтальмологом, 460 хв. - дієтологом, 179 хв. - фізіотерапевтом, 51 хв. - проктологом, a RRS проведено 1464 хв. Всього у 2018 р. проведено 5515 консультацій вузькими спеціалістами, на одного хворого приходилось - 1,5. Проведено 24257 прийомів лікарями, тобто по 6,5 прийомів на хворого. Це дуже висока цифра, враховуючи, що тільки 37,5 \% лікувалось повний термін 21-24 дні.

За 2018 р. було зроблено знімків - 265 хворим, зроблено 838 обстежень і рентгенпросвічень 229 хв., зроблено 756 обстежень. Відсоток охоплення дещо збільшився.

За 2018 р. в клінічній лабораторії обстежено 3920 хв., проведено 47165 обстежень, по 12 на хворого.

У кабінеті ендоскопії відділення «Санаторій «Лаванда»» за 2018 р. обстежено 1251 хворого. Охоплено 33,3 \% хворих, проведено 1464 хворим ректоманоскопію, тобто охоплено $39 \%$, а за 2017 р. обстежено 1123 хворих. Охоплено - 26 \% хворих. Проведено 1574 хв. ректоманоскопії, тобто охоплено 36,6\%.

За 2018 р. обстежено методом ультразвукової діагностики 3899 хворих, проведено 9496 обстежень, по 2,4 обстежень на хворого. Охоплено хворих 103,9\%. Функціонує кабінет рефлексотерапії. Використовуються наступні лікувальні методики: класична голкотерапія, аурікулотерапія, голки-банки НАCI, аплікатор Ляпко, припалювання полинними цигарками, мануальна терапія. Функціонує стоматологічний кабінет.

У «Санаторій «Лаванда»» $є$ один зал площею 112 кв. м. для проведення лікувальної фізкультури. Штат: 1 інструктор 3 фізкультури (з вищою освітою).

Кабінет ЛФК працює кожен день. Шість разів на тиждень.

Проводяться групові заняття й індивідуальні. Упродовж робочого часу відпускається механотерапія.

За 2018 рік у залі ЛФК оздоровилось лікувальною фізкультурою 938 чол., надано всього 8542 процедури. Крім того, 61 людина направлена на групову нордичну ходьбу. Проведено 534 заняття. Функціонує автоматичний масажний апарат «Релакс». Детальний аналіз діяльності кабінету ЛФК поданий у табл.1. 
Аналіз діяльності кабінету ЛФК

Таблиця 1

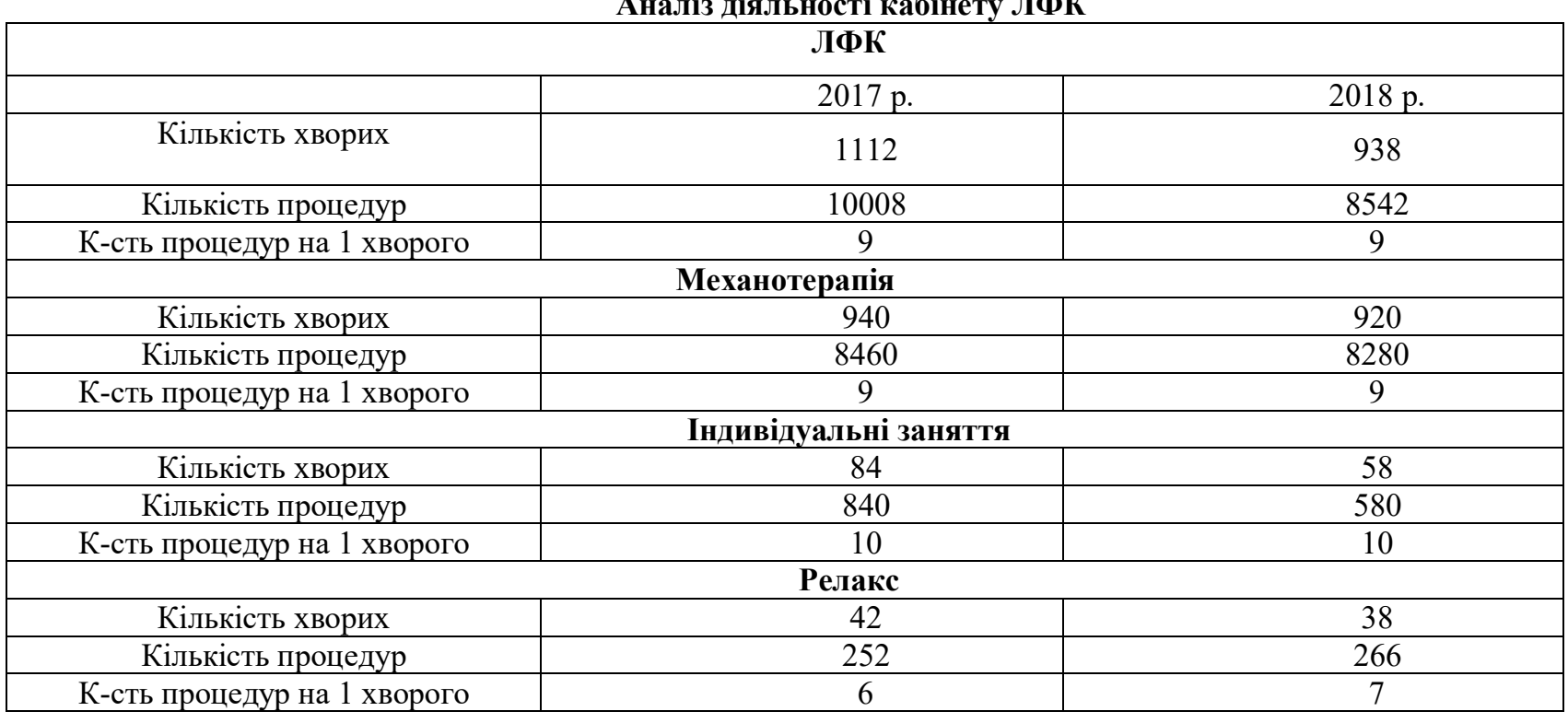

Їдальня санаторію „Лаванда” обслуговує хворих санаторію „Лаванда”, займає один будинок і розрахована на 400 посадкових місць в одну зміну. Їдальня працює в одну зміну цілорічно і забезпечує пацієнтів дієтичним харчуванням, відповідно до призначення лікаря.

За 2018 р. прийнято 3 діагнозом захворювання печінки 170 хворих, що становить 4,5\%, а за 2017 p. прийнято 3 діагнозом захворювання печінки 199 хворих, що становить 4,6 \%. У відсотковому відношенні кількість таких хворих майже не змінилась.

До лікування гепатитів у 2018 році лікарі підходили диференційовано, використовували не тільки природні фактори, але й медикаментозне лікування, враховуючи, що гепатит - це патологія, яка викликає значні органічні зміни. Всі хворі виписані 3 покращенням.

За 2018 р. прийнято з діагнозом захворювання жовчного міхура та жовчних шляхів - 1296 хв., що становить $34,5 \%$.

У Відділенні «Санаторій «Лаванда»»» проходять реабілітацію пацієнти у підгострому періоді після оперативних втручань на органах травлення (відділення на 60 ліжок).

Стандарти санаторно-курортного лікування складено на основі «Рекомендованих стандартів санаторно-курортного лікування» під редакцією Е.О. Колесника, К.Д. Бабова, М.П. Дриньковського», м. Київ, 2003 р., «Методичних рекомендацій з санаторно-курортного лікування» під редакцією доктора медичних наук, професора М.В. Лободи ЗАТ „Укрпрофоздоронвиця" м. Київ, 1998 р. та клінічних протоколів. Термін лікування коливався від 18 до 24 днів за бажанням хворого $[1,2]$.

У 2018 році виписано 359 реабілітаційних хворих. Ваннами охоплено 331 хв., тобто 92,7 \%, по 8,6 процедур на хворого. Відпущено 2833 ванни. Лікувальні душі приймало 179 осіб, проведено 1510 процедур, по 8,4 процедур на хворого, охоплено 50,1 \% хворих. 3,6 \% хворих приймало місцевий висхід- ний душ та 5,6 \% приймали душ Шарко, 97 \% охоплено фізіотерапією. Найчастіше призначалась фітотерапія (47\%), магнітотерапія (59,9\%), лазеротерапія (10,6 \%), СКТ (44,5 \%), інгаляція (15,1\%), світлолікування (9,5\%), ультразвукова терапія (19,9\%), озекерітолікування $(24,6 \%)$, мікроклізми $(67,5 \%)$, кишкові зрошення $(8,4 \%)$, оксигенотерапія $(25,5 \%)$.

Реабілітаційні хворі прибували після стаціонарного лікування обстежені, але додатково було призначено: електрокардіографію - 280 хв. - 78,4 \%; ректороманоскопію - 56 хв. - 15,7 \%; фіброгастроскопію - 35хв. - 9,8 \%; клінічну діагностику - 23 0хв. - 64,4 \%; біохімічну - 286 хв. $-80 \%$; імунологічну 10 хв. - 2,8 \%; ультразвукову діагностику - 128хв. $36 \%$; ренгендіагностику -8 хв. $-2,3 \%$.

Основними критеріями якості реабілітації вважалося: поліпшення загального самопочуття, зникнення диспепсичних явищ, болю, порушень апетиту, розладу випорожнення, пальпаторної болючості живота, нормалізація показників інструментальних та лабораторних досліджень[3].

Практика лікування показала, що санаторнокурортне лікування потрібно застосовувати не тільки при хронічних стадіях хвороби, а у більш ранні строки, після перенесеного гострого захворювання, що запобігає його розвитку, скорочує строк тимчасової непрацездатності, сприяє реабілітації хворого.

Висновки. У Відділенні «Санаторій «Лаванда»») за 2018 рік закінчило лікування 3753 хворих, 3 них із гастроентерологічними захворюваннями 3057 хворих, тобто 81,5 \%. Троє хворих мали протипоказання і були виписані протягом 3 днів.

Найбільше хворих було із захворюваннями жовчовивідних шляхів та печінки, гастритом, виразковою хворобою шлунка та 12-палої кишки. Порівнюючи 32017 р., кількість хворих зменшилась. Усі хворі виписані із покращенням.

По лікувальних процедурах збільшився відсоток охоплення тепловими процедурами за рахунок збільшення відсотка охоплення водними процедура- 
ми. Збільшилась кількість лікувальних процедур у самому санаторії (мікроклізм, рефлексотерапії, ЛФК). Хворі санаторію «Лаванда» проконсультовані гінекологом, урологом, невропатологом, отоларингологом, хірургом, дерматовенерологом, ендокринологом, офтальмологом, проктологом, травматологом та дієтологом. Всього в 2018p. проведено 5515 консультацій вузькими спеціалістами, на одного хворого приходилось - 1,5. Проведено 24257 прийомів лікарями, тобто по 6,5 прийомів на хворого. Це дуже висока цифра, враховуючи, що тільки 37,5 \% лікувалось повний термін 21-24 дні.

Кадрові, природні, матеріальні ресурси та лікувальна діяльність Відділення «Санаторій «Лаванда»»» санаторно-курортного комплексу «Моршинкурорт» свідчать про великий реабілітаційний потенціал даного закладу при різних соматичних захворюваннях. Проте у світлі реформ та нововведень, можливо, доцільно залучати у мультипрофесійну команду, яка здійснює реабілітаційний процес, також лікарів фізичної реабілітаційної медицини, а замість інструктора ЛФК ввести посаду фізичного терапевта, для застосування більш нових методів фізичної терапії з точки зору доказової медицини.

\section{References:}

1. Medychni (balneolohichni) vysnovky vydani DU «Ukrayinskyy NDI medychnoyi reabilitatsiyi ta kurortolohiyi MOZ Ukrayiny» vid 28.02.2012. P.357, 358, 359, 360 dlya DP «SKK «Morshynkurort».

2. Postanova FSS Ukrayiny №39 vid 13.07.2017. «Pro zatverdzhennya Poryadku vidshkoduvannya vytrat za nadani sotsial'ni posluhy z likuvannya zastrakhovanykh osib ta chleniv yikh simey pislya perenesenykh zakhvoryuvan' i travm u reabilitatsiynykh viddilennyakh sanatorno-kurortnykh zakladiv za rakhunok koshtiv Fondu sotsial'noho strakhuvannya Ukrayiny».

3. Churpiy KL. Reabilitatsiya khvorykh pokhyloho ta starechoho viku z hostrym kholetsystytom u rann'omu pislyaoperatsiynomu periodi / Churpiy KL, Churpiy IK, Churpiy VK / Halyts'kyy likars'kyy visnyk. 2012; 19(3):146-147.

\section{УДК $615.8+616-089+616.366$ \\ АНАЛИЗ МЕТОДИКИ РЕАБИЛИТАЦИИ ПА- ЦИЕНТОВ ПОСЛЕ ХОЛЕЦИСТЭКТОМИИ НА ОТДАЛЕННОМ ЭТАПЕ РЕАБИЛИТАЦИИ В ОТДЕЛЕНИИ «ЛАВАНДА» САНАТОРНО- КУРОРТНЫЙ КОМПЛЕКС «МОРШИНКУ- POPT»}

Н.Р. Голод ${ }^{1}$, И.К. Чурпий ${ }^{1}$, Н. Слободян ${ }^{2}$, Н.М. Мукан ${ }^{2}$, А.В. Янив ${ }^{1}$

\footnotetext{
${ }^{1}$ Івано-Франковский национальный медицинский университет, кафедра физической реабилитации, эрготерапии и физического воспитания,

2. Ивано-Франковск, Украина,

ORCID ID: 0000-0003-0996-6920,

e-mail: natasha777@i.ua,afex@ukr.net, ORCID ID: 0000-0003-1735-9418,

e-mail: ch.igor.if@gmail.com,
}

ORCID ID: 0000-0003-0921-3304,

e-mail: olesiayaniv333@gmail.com;

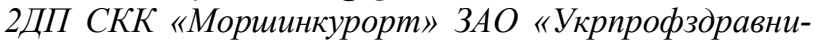
ияа», г. Мориин, Львовская обл., Украина

Резюме. Цель исследования: провести анализ методики реабилитации пациентов после холецистэктомии на отдаленном этапе реабилитации в Отделении «Санаторий «Лаванда»» санаторно-курортного комплекса «Моршинкурорт».

Методы исследования: анализ методов реабилитации пациентов в Отделении «Санаторий «Лаванда»»» санаторно-курортного комплекса «Моршинкурорт» за 2017 и 2018 годы, синтеза и анализа.

В Отделении «Санаторий «Лаванда»» проходят реабилитацию пациенты в подостром периоде после оперативных вмешательств на органах пищеварения (отделение на 60 коек). В 2018 году выписано 359 реабилитационных больных. Ваннами охвачено 331 больного, то есть 92,7\% по 8,6 процедур на больного. Отпущено 2833 ванны. Лечебные души принимало 179 человек, проведено 1510 процедур, по 8,4 процедур на больного, охвачено 50,1 \% больных. $3,6 \%$ больных принимало местный восходящий душ и 5,6\% принимали душ Шарко, 97 \% охвачено физиотерапией. Чаще всего предназначалась фитотерапия $(47 \%)$, магнитотерапия (59,9\%), лазеротерапия $(10,6 \%)$, СКТ $(44,5 \%)$, ингаляция $(15,1 \%)$, светолечение $(9,5 \%)$, ультразвуковая терапия $(19,9 \%)$, озекеритолечение приняло $24,6 \%$, микроклизмы $67,5 \%$, кишечные орошения $-8,4 \%$, оксигенотерапию - 25,5\%.

Выводы. Кадровые, природные, материальные ресурсы и лечебная деятельность отделения свидетельствуют о большом реабилитационном потенциале данного заведения при различных соматических заболеваниях. Однако, в свете реформ и нововведений, возможно, целесообразно привлекать в мультипрофесиональную команду, которая осуществляет реабилитационный процесс, также врачей физической реабилитационной медицины, а вместо инструктора ЛФК ввести должность физического терапевта, для применения более новых методов физической терапии с точки зрения доказательной медицины.

Ключевые слова: реабилитация, холецистэктомия, санаторно-курортный этап.

UDC $615.8+616-089+616.366$
THE REHABILITATION METHODS ANALYSIS
OF PATIENTS AFTER CHOLECYSTECTOMY AT
THE REMOTE STAGE OF REHABILITATION IN
THE DEPARTMENT “LAVENDER" AT SANATO-
RIUM-RESORT COMPLEX “MORSHYNKU-
RORT"

I.K. Churpiy ${ }^{1}$, N.R. Golod ${ }^{1}$, N.G. Slobodian ${ }^{2}$, N.M. Mukan ${ }^{2}$, O.V. Yaniv ${ }^{1}$ 
${ }^{1}$ Ivano-Frankivsk National Medical University, Department of Physical Rehabilitation, Ergotherapy and Physical Education, Ivano-Frankivsk, Ukraine,

ORCID ID: 0000-0003-0996-6920,

e-mail:natasha_777@i.ua,afex@ukr.net, ORCID ID: 0000-0003-1735-9418, e-mail:ch.igor.if@gmail.com,

ORCID ID: 0000-0003-0921-3304, e-mail: olesiayaniv333@gmail.com;

${ }^{2} S R K$, subsidiary Morshynkurort of Ukrprofozdorovnytsia, CJSC, Morshyn city, Lviv region, Ukraine.

Abstract. The aim of the study is to analyze the method of rehabilitation of patients after cholecystectomy at a remote stage of rehabilitation in the Department of Sanatorium "Lavender" of sanatorium-resort complex "Morshynkurort".

Methods of research: analysis of methods of patient rehabilitation in the department "Lavender "of sanatorium-resort complex "Morshynkurort" during 2017 and 2018, methods of mathematical statistics, synthesis and analysis.

At the Sanatorium Department "Lavender" 3753 patients have completed treatment during 2018, including $3057(81.5 \%)$ patients with gastroenterological diseases. Three patients were contraindicated to the treatment and were discharged within 3 days.

Most patients suffered from diseases of the biliary tract and liver, gastritis, peptic ulcer and duodenal ulcer.

At the Sanatorium Department "Lavender", patients undergo rehabilitation in the subacute period after surgery on the digestive system (60 beds in the department).

Standards of sanatorium and spa treatment of the department is made on the basis of "Recommended standards of sanatorium and spa treatment" editered by E.A. Kolesnyk, K.D. Babov, M.P. Drinkovsky (Kyiv. 2003); Methodical recommendations for spa treatment edited by Doctor of Medical Sciences, Professor M.V. Loboda, (Kyiv, 1998); and clinical protocols. The treatment period ranged from 18-24 days at the request of the patient.

In 2018, 359 rehabilitation patients were discharged. 331 patients took medical baths (92.7\%), 8.6 procedures per patient. There were performed 2833 baths. 179 patients took therapeutic showers, 1510 procedures were performed, 8.4 procedures per patient; In general, $50.1 \%$ of patients were enrolled. $3.6 \%$ of patients took a local rising shower and 5.6\% took a Sharko shower, 97\% were involved in physiotherapy. The most frequently prescribed was phytotherapy (47\%), magnetotherapy $(59.9 \%)$, laser therapy $(10.6 \%)$, SKT $(44.5 \%)$, inhalation $(15.1 \%)$, phototherapy $(9.5 \%)$, ultrasound therapy $(19.9 \%)$, ozokerite treatment $(24.6 \%)$, microclysis $(67.5 \%)$, intestinal irrigation $(8.4 \%)$, oxygen $(25.5 \%)$. The total number of consultations by narrow specialists in 2018 is about 5515, (1.5per patient). 24257 appointments at the doctors were made, that is -6.5 appointment per patient.

Reflexology therapy is also functioning. The following therapeutic techniques are used: classic acupuncture, auriculotherapy, needles, Lyapko applicator, manual therapy. There is a dental office as well.

The main criteria for the quality of rehabilitation were improvement of general well-being, disappearance of dyspeptic phenomena, pain, appetite disorders, stool disorders, abdominal pain at palpation, normalization of instrumental and laboratory tests.

Conclusions. Personnel, natural, material resources and medical activity of the sanatorium "Lavender" of the sanatorium-resort complex "Morshynkurort" testifies to the great rehabilitation potential of this institution in various somatic diseases. However, in the light of reforms and innovations, it may be advisable to involve physicians in the rehabilitation process as well as physicians in the field of rehabilitation medicine, and to introduce a physical therapist instead of an LFK instructor to apply newer methods of physical therapy in the context of evidence-based medicine.

Keywords: rehabilitation, cholecystectomy, sanatorium-spa stage. 